\title{
Kompetensi PPL Mahasiswa Prodi Pendidikan Matematika UMRAH Ditinjau dari Perspektif Guru Pamong
}

\author{
Rezky Ramadhona ${ }^{1, *}$, Mirta Fera ${ }^{2}$ \\ 1,2 Universitas Maritim Raja Ali Haji \\ *ramadhona@umrah.ac.id \\ \begin{tabular}{|l|l|l|}
\hline Received : $29-11-2019$ & Revised: $14-2-2020$ & Accepted: $5-3-2020$
\end{tabular}
}

\begin{abstract}
ABSTRAK
Mahasiswa prodi pendidikan matematika merupakan calon guru matematika. Oleh karena itu mereka harus memiliki kompetensi dasar seorang guru yaitu kompetensi pedagogi, individu, sosial, dan profesional. Penelitian ini bertujuan untuk mengetahui kompetensi dasar yang dimiliki mahasiswa sebagai calon guru pada saat PPL di sekolah. Jenis penelitian yang digunakan adalah penelitian deskriptif kuantitatif. Subjek penelitian nya adalah 36 guru pamong dari 32 sekolah praktikan. Teknik pengumpulan data yaitu menggunakan angket perspektif guru pamong dengan instrumen pengumpulan data adalah lembar angket. Hasil penelitian ini menunjukkan bahwa kompetensi PPL mahasiswa berada pada kategori kompeten. Tingkat pencapaian kompetensi pedagogi mahasiswa adalah $82,74 \%$ dengan kategori kompeten, kompetensi kepribadian adalah $87,00 \%$ dengan kategori kompeten, kompetensi sosial adalah 85,23\% dengan kategori kompeten dan Kompetensi profesional adalah 81,76\% dengan kategori kompeten.
\end{abstract}

Kata kunci: Kompetensi PPL Mahasiswa, Perspektif, Guru Pamong

\begin{abstract}
Mathematics study program students are prospective mathematics teachers. Therefore they must have the basic competencies of a teacher namely pedagogical, individual, social, and professional competencies. This study aims to determine the basic competencies students have as prospective teachers at PPL at school. This type of research is a quantitative descriptive study. The research subjects were 36 tutor teachers from 32 practice schools. The data collection technique is using a tutor perspective teacher questionnaire with data collection instruments is a questionnaire sheet. The results of this study indicate that PPL student competencies are in the category of competencies. The achievement level of student pedagogy competence is $82.74 \%$ with the competent category, personality competence is $87.00 \%$ with the competent category, social competence is $85.23 \%$ with the competent category and professional competence is $81.76 \%$ with the competent category.
\end{abstract}

Keywords: Student Competencies at PPL, Perspective, Tutor Teacher 


\section{PENDAHULUAN}

Kualitas pendidikan di Indonesia dinilai banyak kalangan masih rendah dibandingkan dengan negara-negara tetangga. Salah satu penyebab rendahnya kualitas pendidikan di Indonesia adalah lulusan dari sekolah atau perguruan tinggi yang belum siap memasuki dunia kerja karena kompetensi yang dimiliki masih minim (Godwin, 2017). Upaya untuk meningkatkan kualitas pendidikan dapat dilakukan salah satunya melalui peningkatan kualitas guru (Syawahid dan Pardi, 2016:2).

Guru sebagai pendidik mempunyai peranan yang penting dalam era globalisasi yang berlangsung saat ini (Oviyanti, 2016). Guru yang profesional adalah guru yang melaksanakan fungsi dan tujuan sekolah dengan baik serta memiliki kompetensi standar dan melaksanakan tugasnya secara optimal (Praharani, 2007). Pembelajaran bagi calon guru dirancang agar calon guru memiliki kompetensi dalam melaksanakan pembelajaran. Pendidikan sangat erat kaitannya dengan belajar. Belajar memiliki tujuan yang mengarah ke pengembangan yang unggul dan tinggi potensi manusia yang berkualitas. Keberhasilan proses pembelajaran sangat dipengaruhi oleh peran guru dalam perencanaan, menerapkan, dan mengevaluasi pembelajaran proses dan hasil (Inayah, Septian, \& Suwarman, 2020). Oleh karena itu, calon guru harus mempraktikkan ilmu yang didapat selama perkuliahan terlebih dahulu di sekolah-sekolah yang telah ditunjuk menjadi tempat praktik mengajar.

Praktik Pengalaman Lapangan (PPL) merupakan salah satu mata kuliah (MK) yang ada di Prodi Pendidikan Matematika UMRAH pada semester 7. Pada MK PPL ini mahasiswa mengaplikasikan ilmu yang telah diperoleh selama perkuliahan di sekolah praktikan. Secara khusus PPL disebut juga praktik pembelajaran dan kegiatan lain yang ada kaitan dengan proses pembelajaran di sekolah.

Guru pamong merupakan guru mata pelajaran yang ditunjuk oleh sekolah yang bertugas membimbing, mendidik, dan membantu mahasiswa PPL selama melakukan praktik di sekolah. Sebelum praktikan mengajar di kelas, terlebih dahulu praktikan melakukan observasi terhadap pembelajaran yang dilakukan oleh guru pamong (Mardiyono, 2006).

Pada pelaksanaan PPL di sekolah dalam beberapa tahun ini terdapat persoalan yang dilaporkan oleh guru pamong, seperti beberapa praktikan yang masih kurang dalam hal bersosialisasi dengan guru atau lingkungan sekitar, pemanfaatan sumber atau media pembelajaran yang masih terbatas, serta masih kurangnya perhatian terhadap penggunaan bahasa dalam berkomunikasi (Fitria \& Fidesrinur, 2018). Jika hal ini tidak diatasi maka 
akan menimbulkan permasalahan bagi sekolah praktikan maupun bagi kualitas lulusan prodi pendidikan matematika yang akhirnya berujung kepada rendahnya kualitas pendidikan di Indonesia. Oleh karena itu, perlu ditinjau bagaimana kompetensi yang dimiliki mahasiswa selama melakukan PPL di sekolah.

Kompetensi merupakan pengetahuan, keterampilan, dan nilai-nilai dasar yang direfleksikan dalam kebiasaan berfikir dan bertindak secara konsisten dan terus menerus yang memungkinkan seseorang itu menjadi kompeten, dalam arti memiliki pengetahuan dasar untuk melakukan sesuatu. Sedangkan kompetensi PPL mahasiswa sebagai calon guru yang dimaksud adalah seperangkat pengetahuan, keterampilan, dan perilaku yang harus dimiliki, dihayati, dikuasai dan diaktualisasi oleh mahasiswa dalam melaksanakan tugas keprofesionalannya sebagai calon guru.

Kompetensi PPL mahasiswa yang dimaksud dalam penelitian ini mengacu kepada kompetensi dasar guru menurut UU No.14 Tahun 2005 tentang Guru dan Dosen yang menyatakan bahwa kompetensi yang harus dimiliki oleh guru adalah kompetensi pedagogik, kepribadian, sosial, dan profesional(kemendikbud, 2016).

Oleh karena itu, rumusan penelitian ini adalah bagaimana perspektif guru pamong terhadap kompetensi PPL mahasiswa program studi pendidikan matematika UMRAH Sehingga penelitian ini bertujuan untuk mendeskripsikan perspektif guru pamong terhadap kompetensi PPL mahasiswa program studi pendidikan matematika UMRAH.

\section{METODE PENELITIAN}

Penelitian ini merupakan penelitian deskriptif (Creswell, 2007) yang memberikan gambaran atau uraian atas suatu keadaaan sejelas mungkin tanpa ada perlakuan terhadap objek yang diteliti. Subjek dalam penelitian ini adalah guru-guru matematika SMP/SMA sederajat yang pernah menjadi guru pamong mata pelajaran matematika. Objek penelitian nya adalah perspektif guru pamong terhadap kompetensi PPL mahasiswa program studi pendidikan matematika.

Teknik pengumpulan data dalam penelitian ini adalah dengan menggunakan angket. Sedangkan instrumen pengumpulan data adalah lembar angket yang terdiri dari 25 pernyataan sesuai dengan indikator kompetensi dasar guru. Indikator dapat dilihat pada Tabel 1. 
Tabel 1. Indikator Kompetensi Dasar Guru

\begin{tabular}{|c|c|c|}
\hline No & Kompetensi & Indikator \\
\hline 1 & Pedagogi & $\begin{array}{l}\text { 1. Menguasai karakteristik peserta didik dari aspek fisik, } \\
\text { moral, spiritual, sosial, kultural, emosional, dan intelektual } \\
\text { 2. Menguasai teori belajar dan prinsip-prinsip pembelajaran } \\
\text { yang mendidik } \\
\text { 3. Menyelenggarakan pembelajaran yang mendidik } \\
\text { 4. Menyelenggarakan penilaian dan evaluasi proses dan hasil } \\
\text { belajar }\end{array}$ \\
\hline 2 & Kepribadian & $\begin{array}{l}\text { 1. Bertindak sesuai dengan norma agama, hukum, sosial, dan } \\
\text { kebudayaan nasional Indonesia } \\
\text { 2. Menampilkan diri sebagai pribadi yang jujur, berakhlak } \\
\text { mulia, dan teladan bagi peserta didik dan masyarakat } \\
\text { 3. Menunjukkan etos kerja, tanggung jawab yang tinggi, dan } \\
\text { rasa percaya diri. }\end{array}$ \\
\hline 3 & Sosial & $\begin{array}{l}\text { 1. Bersikap inklusif, bertindak objektif, serta tidak } \\
\text { diskriminatif karena pertimbangan jenis kelamin, agama, } \\
\text { ras, kondisi fisik, latar belakang keluarga, dan status sosial } \\
\text { ekonomi. } \\
\text { 2. Berkomunikasi secara efektif, empatik, dan santun dengan } \\
\text { sesama pendidik, tenaga kependidikan, orang tua, dan } \\
\text { masyarakat } \\
\text { 3. Beradaptasi di tempat bertugas yang memiliki keragaman } \\
\text { sosial budaya }\end{array}$ \\
\hline 4 & Profesional & $\begin{array}{l}\text { 1. Menguasai materi } \\
\text { 2. Mengembangkan materi pembelajaran secara kreatif. }\end{array}$ \\
\hline
\end{tabular}

Teknik analisis data yang digunakan adalah teknik analisis statistik deskriptif. Pengolahan data dilakukan dengan menggunakan program Microsoft Excel. Nilai penguasaan setiap kompetensi dapat diketahui dengan menggunakan perhitungan sebagai berikut:

$$
\text { Penguasaan Kompetensi (skala 100) }=\frac{\text { Skor yang didapat }}{\text { skor total }} \times 100 \%
$$

Hasil penilaian penguasaan kompetensi selanjutnya dikonversikan dengan mengacu pada kategori yang ada pada Tabel 2 .

Tabel 2 Kategori Kompetensi

\begin{tabular}{ccc}
\hline No & Tingkat Pencapaian $(\%)$ & Kategori \\
\hline 1 & $91-100$ & Sangat Kompeten \\
\hline 2 & $76-90$ & Kompeten \\
\hline 3 & $61-75$ & Cukup Kompeten \\
\hline 4 & $51-60$ & Kurang Kompeten \\
\hline 5 & $0-50$ & Tidak Kompeten \\
\hline
\end{tabular}




\section{HASIL DAN PEMBAHASAN}

Penelitian dilakukan terhadap 36 guru pamong yang berasal dari 32 sekolah SMP/MTsN dan SMA/SMK sederajat yang ada di kota Tanjungpinang dan Kabupaten Bintan. Adapun hasil analisis angket perspektif guru pamong terhadap kompetensi PPL mahasiswa prodi pendidikan matematika dapat dilihat pada Gambar 1 .

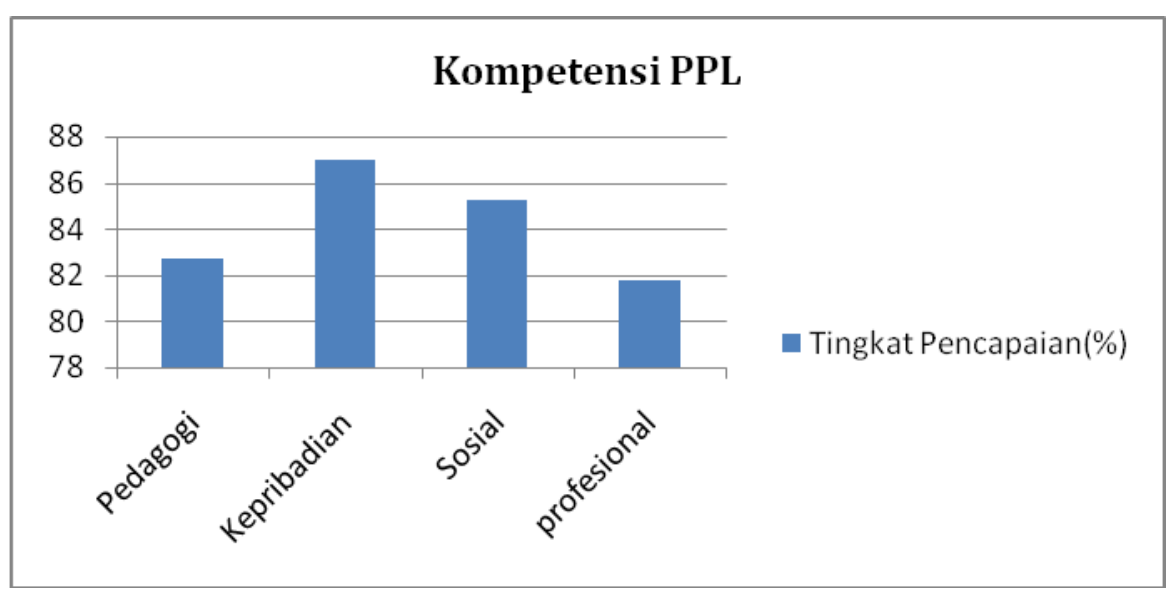

Gambar 1. Tingkat Pencapaian Kompetensi PPL Mahasiswa

Berdasarkan Gambar 1, maka dapat diketahui bahwa tingkat pencapaian kompetensi PPL mahasiswa prodi pendidikan matematika berada di atas $80 \%$ dengan kategori "kompeten". Pencapaian tertinggi terletak pada kompetensi kepribadian yaitu sebesar $87 \%$ dengan kategori kompeten. Ini menunjukkan rata-rata mahasiswa PPL prodi pendidikan matematika FKIP UMRAH menghargai peserta didik tanpa membedakan keyakinan yang dianut, suku, adat-istiadat, daerah asal, dan gender serta berprilaku sopan, jujur dan berakhlak mulia kepada semua warga sekolah. Selain itu mahasiswa juga berpenampilan rapi dan sopan baik di dalam maupun di luar kelas, serta menunjukkan etos kerja, tanggung jawab yang tinggi, dan rasa percaya diri. Hal ini telah sesuai dengan yang tertuang dalam UU No.14 Tahun 2005 tentang Guru dan Dosen.

Kompetensi kepribadian merupakan titik tolak agar seorang guru bisa sukses, jika kepribadiaan guru mantap, maka setiap tindakannya akan sesuai dengan norma-norma yang berlaku. Oleh karena itu untuk menciptakan peserta didik yang berkarakter maka perlu dimulai dari kepribadian guru yang mantap. Hal ini sejalan dengan yang disampaikan Sudrajat bahwa "penguasaan kompetensi kepribadian yang memadai dari seorang guru akan sangat membantu upaya pengembangan karakter siswa". 
Tingkat pencapaian untuk setiap kompetensi dapat dijabarkan sebagai berikut:

a. Kompetensi Pedagogi

Pada kompetensi pedagogi terdapat 4 indikator yang dilihat yang pertama menguasai karakteristik peserta didik dari aspek fisik, moral, spiritual, sosial, kultural, emosional, dan intelektual. Indikator ke dua yaitu menguasai teori belajar dan prinsipprinsip pembelajaran yang mendidik. Indikator ke tiga yaitu menyelenggarakan pembelajaran yang mendidik dan indikator ke empat adalah menyelenggarakan penilaian dan evaluasi proses dan hasil belajar. Hasil pencapaian untuk setiap indikator dapat dilihat pada Gambar 2.

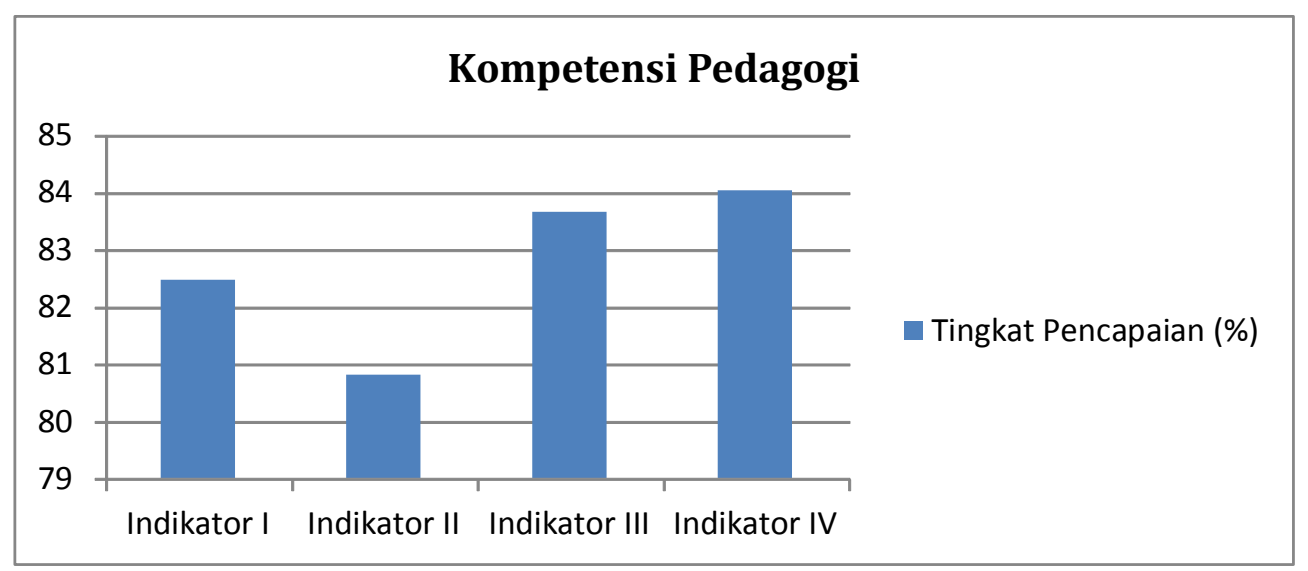

Gambar 2. Tingkat Pencapaian Kompetensi Pedagogi

Berdasarkan Gambar 2 terlihat bahwa indikator ke empat yaitu menyelenggarakan penilaian dan evaluasi proses dan hasil belajar mendapat nilai tertinggi. Ini menunjukkan bahwa setiap mahasiswa membuat lembar penilaian dan evaluasi untuk proses dan hasil belajar serta selalu memeriksa hasil kerja siswa.

Berdasarkan hasil analisis rata-rata kemampuan pedagogi mahasiswa PPL sudah berada pada kategori kompeten. Ini berarti mahasiswa sudah terampil dalam menggunakan strategi maupun model pembelajaran. Serta mahasiswa sudah berusaha memahami perbedaan individu siswa baik dari aspek fisik, moral, spritual, dan intelektual. Hal ini telah sesuai dengan yang dsampaikan Syawahid dan Pardi (2016:5) bahwa kompetensi pedagogik merupakan kompetensi guru dalam mengelola pembelajaran yang berhubungan dengan peserta didik.

b. Kompetensi Kepribadian

Indikator kompetensi kepribadian yang dilihat yaitu bertindak sesuai dengan norma agama, hukum, sosial, dan kebudayaan nasional Indonesia, menampilkan diri sebagai pribadi yang jujur, berakhlak mulia, dan teladan bagi peserta didik dan masyarakat, serta 
menunjukkan etos kerja, tanggung jawab yang tinggi, dan rasa percaya diri. Tingkat pencapaian kompetensi dapat dilihat pada Gambar 3.

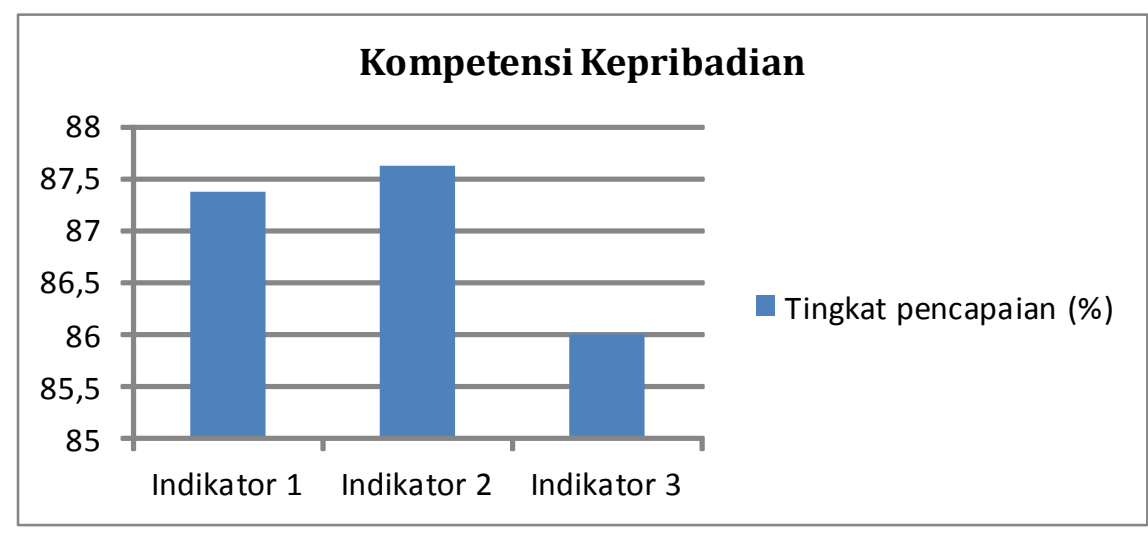

Gambar 3. Tingkat Pencapaian Kompetensi Kepribadian

Gambar 3 menjelaskan bahwa pencapaian tertinggi terdapat pada indikator ke dua yaitu "Menampilkan diri sebagai pribadi yang jujur, berakhlak mulia, dan teladan bagi peserta didik dan masyarakat" sebesar 87,63\% dengan kategori kompeten.

c. Kompetensi Sosial

Kompetensi PPL lain yang perlu dilihat adalah kompetensi sosial. Kompetensi ini menunjukkan bagaimana bersikap, berkomunikasi, dan beradaptasi sesama pendidik, tenaga kependidikan, orang tua, dan masyarakat. Adapun hasilnya dapat dilihat pada Gambar 4.

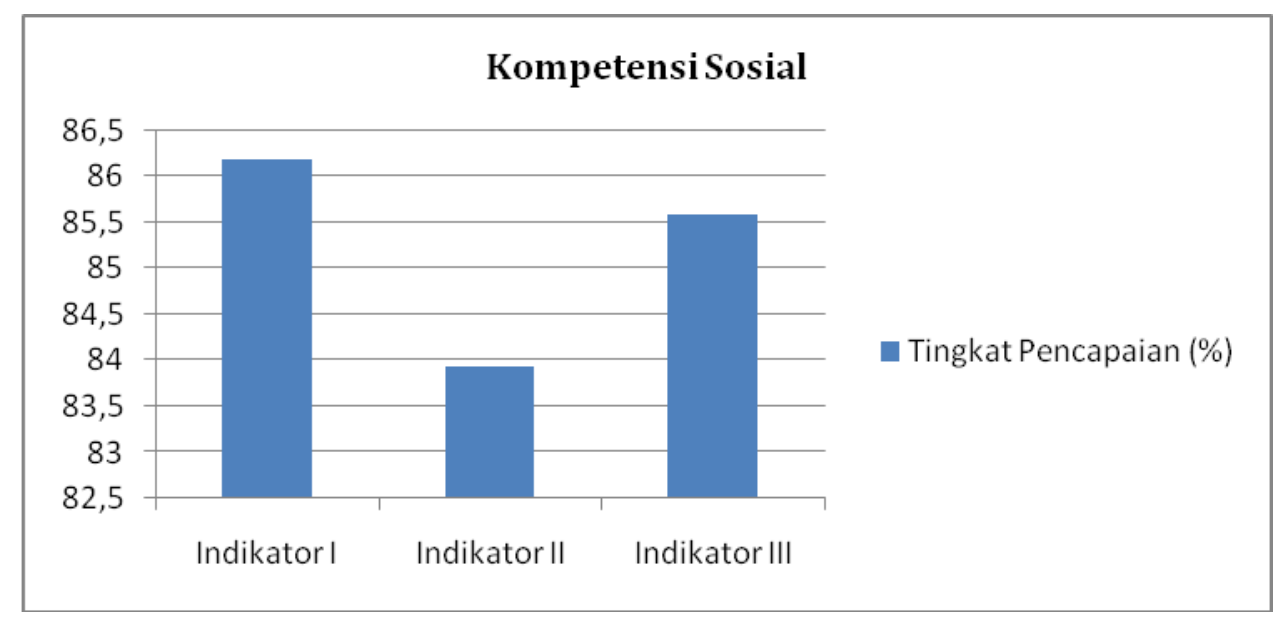

Gambar 4. Tingkat Pencapaian Kompetensi Sosial

Berdasarkan Gambar 4, terlihat bahwa pencapaian yang tertinggi terletak pada indikator I yaitu "Bersikap inklusif, bertindak objektif, serta tidak diskriminatif karena pertimbangan jenis kelamin, agama, ras, kondisi fisik, latar belakang keluarga, dan status sosial ekonomi" dengan nilai $86,2 \%$ pada kategori kompeten. 
Hasil di atas menunjukkan bahwa selain mempunyai kepribadian yang baik ratarata mahasiswa PPL juga memiliki kemampuan sosial yang baik. Mahasiswa praktikan tidak bersikap diskriminatif terhadap peserta didik, teman sejawat karena perbedaan agama, suku, jenis kelamin, latar belakang keluarga, dan status sosial-ekonomi. Serta mahasiswa praktikan mampu bekerjasama dengan teman sejawat dan guru dalam berbagai kegiatan yang dilakukan sekolah.

d. Kompetensi Profesional

Indikator kompetensi profesional yang dilihat ada dua yaitu menguasai materi, dan mengembangkan materi pembelajaran secara kreatif. Adapun hasil angket untuk kompetensi profesional dapat dilihat pada Gambar 5.

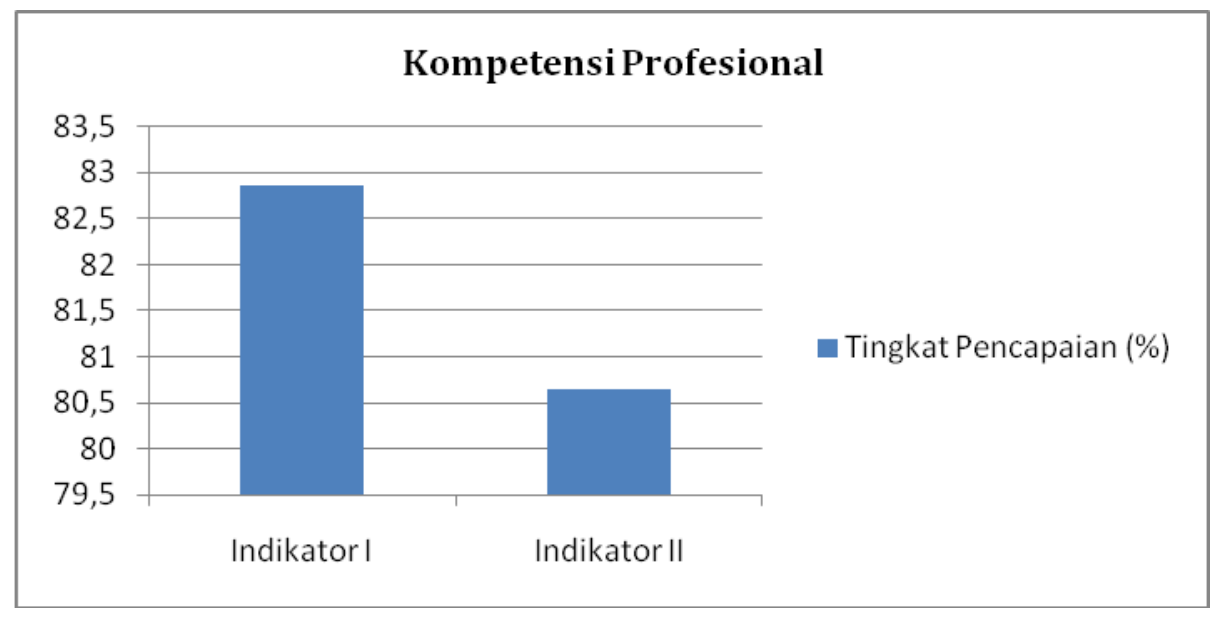

Gambar 5. Tingkat Pencapaian Kompetensi Profesional

Berdasarkan Gambar 5 dapat diketahui bahwa pencapaian tertinggi terletak pada indikator I yaitu "menguasai materi" sebesar 82,86\% dengan kategori kompeten. Sedangkan indikator ke dua yaitu "Mengembangkan materi pembelajaran secara kreatif" dengan indikator ketercapaian 80,65\% dan masih berada pada kriteria kompeten. Indikator ke dua lebih rendah dari indikator pertama karena ada tingkat pencapaian suatu pernyataan yang mendapat nilai $79,7 \%$ dengan kategori kompeten. Pernyataan tersebut adalah "Mahasiswa praktikan menyampaikan materi dengan memanfaatkan IT". Di era serba digital, upaya menciptakan sumber daya manusia yang handal tentunya diperlukan peningkatan kualitas pendidikan dalam berbagai aspek diantaranya matematika (Septian \& Komala, 2019).

Berdasarkan hasil analisis angket dapat dilihat bahwa rata-rata mahasiswa praktikan sudah kompeten. Ini berarti mahasiswa menguasai materi yang akan diajarkan, mampu menjawab pertanyaan yang diajukan siswa dengan baik dan benar, serta telah menyampaikan materi secara kontekstual. Dengan kompetennya kemampuan ini maka 
berpengaruh kepada mutu pembelajaran. Hal ini sejalan dengan yang disampaikan oleh Eko Siswono dan Nur Djulaiqha (2017:50) bahwa "Kompetensi profesional guru memegang peranan penting untuk meningkatkan mutu pembalajaran”.

Selain hasil angket, ada beberapa saran yang disampaikan oleh guru pamong, diantaranya yaitu:

1. mahasiswa harus meningkatkan kreatifitas dalam proses belajar mengajar

2. mahasiswa melaksanakan PPL di sekolah diusahakan tidak dibebankan dengan kegiatan perkuliahan di kampus

3. mahasiswa harus menggali motivasi siswa untuk lebih aktif dan giat dalam belajar

4. mahasiswa harus meningkatkan potensi dirinya

5. mahasiswa diharapkan menggunakan bahasa Indonesia yang baik dan benar dalam mengajar

6. mahasiswa harus meningkatkan kemampuan dalam mengembangkan media pembelajaran berbasis IT.

\section{KESIMPULAN}

Berdasarkan hasil analisis dan pembahasan maka dapat disimpulkan bahwa perspektif guru pamong terhadap kompetensi PPL mahasiswa program studi pendidikan matematika untuk kompetensi pedagogi berada pada kategori kompeten, kompetensi kepribadian terletak pada kategori kompeten, kompetensi sosial terletak pada kategori kompeten, dan kompetensi profesional juga terletak pada kategori kompeten.

\section{REFERENSI}

Creswell, J. W. (2007). Research Design: Qualitative, Quantitative and Mixed Method Aproaches. SAGE Publications, 203-223. https://doi.org/10.4135/9781849208956

Eko Siswono dan Nur Djulaiqha. (2017). Peningkatan Kompetensi Profesional Guru Ips. Edukasi IPS, 1(1), 12-20.

Fitria, N., \& Fidesrinur, F. (2018). Praktik Pengalaman Lapangan. JURNAL Al-AZHAR INDONESIA SERI HUMANIORA, 4(1), 41. https://doi.org/10.36722/sh.v4i1.253

Godwin, R. (2017). Faktor Rendahnya Kualitas Pendidikan Indonesia. RENDAHNYA KUALITAS PENDIDIKAN DI INDONESIA.

Inayah, S., Septian, A., \& Suwarman, R. F. (2020). Student Procedural Fluency in Numerical Method Subjects. Desimal: Jurnal Matematika, 3(1), 53-64. https://doi.org/10.24042/djm.v3i1.5316

kemendikbud. (2016). GURU PEMBELAJAR Pedoman Program Peningkatan Kompetensi. In GURU PEMBELAJAR Pedoman Program Peningkatan Kompetensi (p. 52).

Mardiyono, S. (2006). Praktik pengalaman lapangan terpadu dalam peningkatan kualitas calon guru. Jurnal Cakrawala Pendidikan, 25(1), 57-72. 
https://doi.org/10.21831/cp.v0i1.392

Oviyanti, F. (2016). Tantangan Pengembangan Pendidikan Keguruan di Era Global. Nadwa, 7(2), 267. https://doi.org/10.21580/nw.2013.7.2.562

Praharani, N. S. (2007). Profesionalisme Guru Dalam Upaya Peningkatan Kualitas Pendidikan. Journal of Experimental Psychology: General, 136(1), 23-42.

Septian, A., \& Komala, E. (2019). Kemampuan Koneksi Matematik dan Motivasi Belajar Siswa dengan Mengunakan Model Problem-Based Learning (PBL) Berbantuan Geogebra di SMP. PRISMA, 8(1), 1-13. https://doi.org/10.35194/jp.v8i1.438

Syawahid dan Pardi. (2016). Mahasiswa Calon Guru Matematika. Edukasi, 14(2), 169. https://doi.org/10.1109/TPWRD.2010.2041257 